\title{
Re-evaluation of the Late Jurassic to Early Cretaceous Stratigraphy of Abu Dhabi
}

V. Vahrenkamp* (ADCO), P. Van Laer (ADCO), K. Leyrer (ADCO), D. Popa (ADCO), F. Al Katheeri (ADNOC), P. Razin (University of Bordeaux) \& C. Grélaud (University of Bordeaux)

\section{For abstract, PTO}

No full paper available 


\title{
15173 Re-evaluation of the Late Jurassic to Early Cretaceous stratigraphy of Abu Dhabi
}

\author{
Volker Vahrenkamp (ADCO <vvahrenkamp@adco.ae>), Pierre Van Laer (ADCO), \\ Karl Leyrer (ADCO), Desdemona Popa (ADCO), Faaeza al Katheeri (ADNOC), \\ Philippe Razin (University of Bordeaux, France) and Carine Grélaud (University of Bordeaux, France)
}

The Late Jurassic to Early Cretaceous sequences of the Arabian Platform form a key petroleum province with super-giant carbonate reservoirs. Despite this economic importance and an excellent database the stratigraphy still contains ambiguities with possible alternative interpretations of far-reaching implications.

A re-evaluation of seismic, well and outcrop data reveals in Abu Dhabi a prominent Upper Jurassic angular unconformity with a westward tilt of strata. The Late Jurassic tectonism at the eastern margin of the Arabian Plate caused significant erosion in southeast Abu Dhabi of the Oxfordian to Tithonian Tuwaiq Mountain, Hadrya, Hanifa, Jubaila formations and Arab D Member. This interpretation is in line with progressively older Jurassic subcrops below the unconformity eastward towards the Tethys margin and reported block faulting in Oman. Tilting, exposure and erosion towards the east created an intra-cratonic basin towards the west in western and central Abu Dhabi. Westward progradation of Upper Jurassic third-order cycles may indicate a long duration of tectonism. Periodic restriction during the Tithonian led to carbonate/evaporite cycles of the Arab C to A members onlapping onto the tilted substrata. Evaporitic conditions peaked with the deposition of the Hith anhydrite, which onlaps against a north-south trending central Abu Dhabi high associated with the tectonic tilt. The Hith anhydrite not only forms a regional seal but also contains potentially prospective carbonate stringers. The overall depositional grain is eastward onlap during transgressions and westwards progradation of grainy carbonates during highstands and forced regression. Evaporites formed and eventually amalgamated during forced regression and subsequent early transgression.

The Late Tithonian transgression lapped onto the central Abu Dhabi high both from the west (Manifa shoals) and the east (Mender glauconite). Eventually, open-marine shoals established over the NStrending high in central Abu Dhabi and subsequently prograded eastward during the deposition of the Early Cretaceous Thamama Group. The switch from westward to eastward progradation is associated with platform margin collapse documented in Oman, and points towards a change in large-scale tectonic stress from compression to extension.

The recognition of the tectonic tilt, the angular unconformity, multiple source rock intervals in shallow and deeper platform settings and westward shoal progradation during the Late Jurassic opens the way for a better understanding of stratigraphy at the eastern Arabian Plate margin. This in turn may lead to new play concepts and renewed exploration activity. 